学術論文

\title{
試作ロゴスキーコイルを用いた電磁鋼板の高周波磁気特性測定
}

\section{Measurement of high frequency magnetic properties of electrical steel sheet using prototype Rogowski coil}

\author{
修理＼cjkstart雄大 ${ }^{* 1}$ (学生員)，若林 大輔"1 (正員)，岡 茂八郎 ${ }^{* 1}$ (正員)，榎園 正人 ${ }^{* 1,2}$ (正員）
}

Yuta SHURI (Stu. Mem.), Daisuke WAKABAYASHI ( Mem.), Mohachiro OKA (Mem.), Masato ENOKIZONO (Mem.)

\begin{abstract}
In order to develop a high-efficiency, low-loss, small, high-power, high-speed rotating motor, it is necessary to accurately measure the magnetic properties of electrical steel sheets under PWM excitation. A shunt resistor is generally used for measuring magnetic characteristics, but non-contact current measurement is required. However, iron cores are used in commercially available current measurement sensors, and it is necessary to consider the effects of core characteristics on high-frequency currents. The authors are focusing on Rogowski coils and developing small current / magnetic field sensors specialized for motor and electrical steel sheet evaluation. In this paper, we make a prototype of Rogowski coil, and report on the evaluation of basic electrical characteristics and the results of application to the measurement of magnetic characteristics of electrical steel sheets under sinusoidal excitation and PWM excitation.
\end{abstract}

Keywords: rogowski coil, current sensor, magnetic field, iron loss, magnetic characteristic measurement, electrical steel sheet.

(2019 年 9 月 6 日受付, 2020 年 9 月 28 日再受付)

\section{1 はじめに}

世界の消費電力の $50 \%$ はモータにより消費されてい る。またモータは今後, 様々な分野で活用が期待され ている。このことから, 高効率・低損失且つ小型高出 力・高速回転モータの開発が求められている。これら の要求と共に高速回転駆動時のモータ巻線に流れる高 周波励磁電流や，それによって磁化される電磁鋼板の 高周波磁気特性の正確な評価が必要となる。特に PWM 励磁下の電磁鋼板の磁気特性を測定するには, 高精度な電流測定が求められる。広く使われているシ ヤント抵抗は回路の切断や負荷の増加を考える必要が ある。市販されている電流測定用センサには一般に鉄 心が使用されており, 高周波電流では渦電流による影 響がある。そのため, 鉄心の薄型化の研究も行われて いる[1]。磁気特性の一般的な測定では励磁コイルに流 れる電流から磁界強度を求め, 磁束密度との関係から 鉄損を算出するため, 電流振幅誤差に加え位相誤差も 小さくしなければならない。

そこで, 著者らはコアレスなロゴスキーコイルに着 目し，モータや電磁鋼板評価に特化した小型な電流・ 磁界センサの開発を行っている[2]。既存市販ロゴスキ 連絡先：若林 大輔, 产870-0397 大分県大分市一木 1727 , 日本文理大学工学部機械電気工学科,

e-mail: wakabayashids@nbu.ac.jp

${ }^{* 1}$ 日本文理大学 ${ }^{* 2}$ ベクトル磁気特性技術研究所
ーコイルとの違いについては，ロゴスキーコイルは空 芯で磁気飽和がないため数百 $\mathrm{A}$ 以上の大電流測定用と して開発されているのが一般的である。本研究では数 $\mathrm{A}$ 程度の電流測定を目標とし電磁鋼板の磁気特性測定 用センサとしての活用を目指しているため，ロゴスキ ーコイルについてコイル径や断面積, 巻数などを独自 に調整できるように設計試作した。本論文では，ロゴ スキーコイルの基礎的な動作原理を検証するため, 口 ゴスキーコイルを試作しその電気特性の評価及び，応 用として正弦波励磁下や空芯であるため磁気飽和及び 高調波による渦電流損を無視することができる利点を 活かし PWM 励磁下などの電磁鋼板の磁気特性測定に 使用した結果について報告する。

\section{2 測定原理}

\section{1 ロゴスキーコイルの原理}

Fig.1 にロゴスキーコイルの構造を示す。空芯の環状 コイルで，コイル内部に反しの線を1 ターン巻いた構 造となっている。被測定対象の電流を囲むように円環 コイルを配置し，電流によって作られるアンペールの 法則に従った磁界強度を検出することができる。ロゴ スキーコイルに誘起される電圧 $e$ によって電流 $I$ は式

（1）で算出することができる[3-4]。ここで， $\mu_{0}$ は磁

$$
I=-\frac{2 r}{\mu_{0} N a^{2}} \int e d t
$$


気定数, $\mathrm{N}$ は巻数, $\mathrm{a}$ はコイルの半径, $\mathrm{r}$ は電流からの コイル中心までの半径である。ロゴスキーコイルは誘 起電圧を積分することで電流を測定することができる 非接触電流センサである。

\section{2 検証用試作ロゴスキーコイル}

検証用に試作したロゴスキーコイルの巻枠は円柱 状のドーナツ形状であり，3D プリンタにて作製した。 素材は PLA（ポリ乳酸）である。今回，製作しやすい サイズを優先したため, $r=40 \mathrm{~mm}, a=10.25 \mathrm{~mm}$, 導線の太さ $0.26 \mathrm{~mm}$, 巻数 657 とした。リード線はよ り線とし，アルミシールド内にリード線を通すことで 外部ノイズの低減を行った。また，ロゴスキーコイル では環状コイルの中に戻りの線を通す構造になってい るため, 電流方向と同じ磁束による誘起電圧を低減で きる。その有無による違いを検証するために比較とし て同じ径と巻き数の環状ソレノイドコイルを同様に試 作した。

\section{3 基礎的評価}

Fig.2 にロゴスキーコイル評価測定システムを示す。 研究室内に無限長の直線電流を模擬した環境を用意し 試作したロゴスキーコイルにより電流測定を行う。信 号発生器にて正弦波交流電圧を発生させ電力増幅器を 通じて回路に電流を流す。回路中の交流電流を測定す るために回路に接続されたシャント抵抗間

(PCYR10000B, $0.1 \Omega$ ) の電圧を測定する。同時にロゴ スキーコイルの出力電圧を $12 \mathrm{bit}, 20 \mathrm{MS} / \mathrm{s}$ の $\mathrm{A} / \mathrm{D}$ コン バータを介しパソコンに取り込み，式（1）から電流 を算出した。ノイズ除去のため 16 周期の加算平均化 を行っている。

$$
I_{p r o}=I_{o r i} \frac{I_{S R}}{I_{R C}}
$$

今回の試作コイルでは作り易さを優先したため, $a$ はrよりも十分に小さい条件となっていないため, ロゴ スキーコイルと環状ソレノイドコイルは $50 \mathrm{~Hz}$ におい てシャント抵抗から得られる電流の振幅に合うよう式 （2）で校正した。ここで， $I_{\text {pro }}$ は校正後の電流， $I_{\text {ori }}$ は 校正前の電流， $I_{S R}$ と $I_{R C}$ はそれぞれ $50 \mathrm{~Hz}$ 時のシャン 卜抵抗とロゴスキーコイルの電流の最大值である。

試作ロゴスキーコイルの基礎的評価として以下の 検討を行った。シャント抵抗から得られる電流を基準 とした。

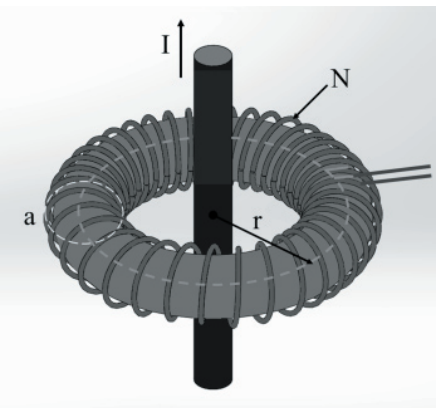

Fig. 1 Rogowski coil.

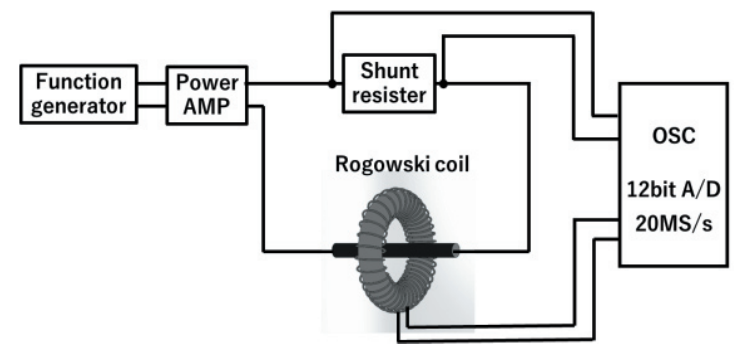

Fig. 2 Measurement system for Rogowski coil.

・ロゴスキーコイルと電流の位置（Fig.3）

・ロゴスキーコイルと電流との角度（Fig.5）

・試作コイルにおいて測定対象の電流に対して直交

する電流を流した場合の影響（Fig.7）

- 周波数に対する振幅誤差率，位相差

Fig.4 にロゴスキーコイルと電流の位置に対する振 幅の変化率を示す。コイル中心の電流を基準とし上下 左右 $25 \mathrm{~mm}$ 移動させ，電流振幅の変化をみた。結果よ り, 中心から離れるにつれ振幅の值は変化するものの 変化率 $0.5 \%$ 程度以内であることが分かる。

Fig.6 はロゴスキーコイルと電流との間の角度 $\theta$ を 変化させたときの振幅の変化率を示す。 $\theta=0$ 。 きはコイルと電流の角度が直角の関係である。角度を 変えると振幅值は変化するものの変化率 $0.6 \%$ 程度で あった。今回試作したロゴスキーコイルは電流の位置 や傾きによっては最大 $1 \%$ 程度の誤差が生じることが 分かった。

Fig.8 は測定対象の電流に対して直交する電流を流 した場合の試作ロゴスキーコイルと環状ソレノイドコ イルが受ける影響を示す（なお，測定対象及び直交す る電流は校正時に用いた $50 \mathrm{~Hz}$ の電流である)。結果よ り, ロゴスキーコイルは誤差 $0.05 \%$ 程度, 環状ソレノ イドコイルは $1.5 \%$ であるため, 環状ソレノイドコイ ルは直交電流による影響を受けやすいことが分かった。 最後に周波数に対する振幅誤差率と位相差につい 


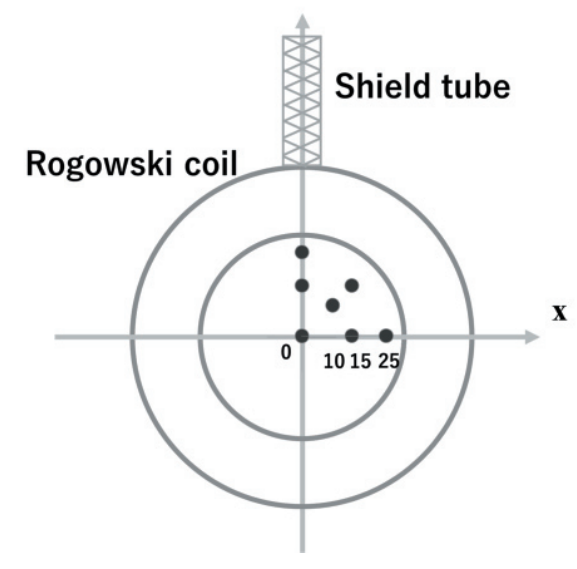

Fig. 3 Change in current position.

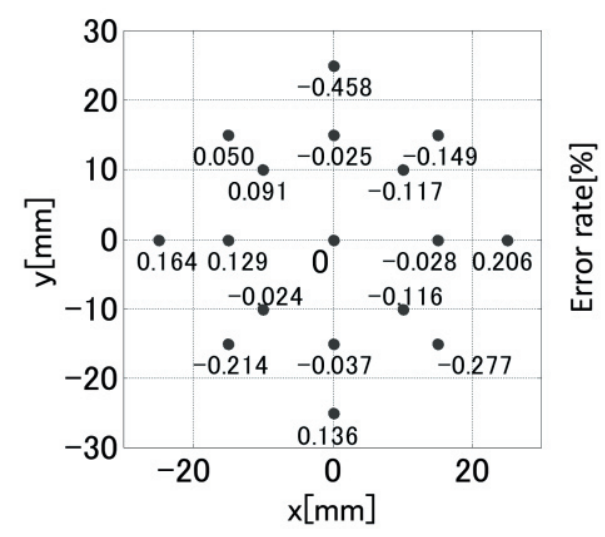

Fig. 4 Rate of change by current position.

て示す。電流位置はコイルの中心とし, $\theta=0^{\circ}$ とし たときの $50 \mathrm{~Hz}$ から $10 \mathrm{kHz}$ の測定を行った。シャント 抵抗から得られる電流を基準とし, 試作したロゴスキ ーコイル，環状ソレノイドコイルから得られる電流， 参考に市販の電流プローブ (HIOKI 9278 : AC/DC ゼロ フラックス方式 (フラックスゲート検出型) ) から得ら れる電流を比較した。これらの関係を詳細に分析した 結果を Fig.9 に示す。Fig.9(a)は周波数に対する振幅誤 差率を示す。周波数の増加に伴い, 振幅誤差率は増加 しているが, 試作したロゴスキーコイルは $10 \mathrm{kHz}$ 以内 で 0.4 \%以下となった。Fig.9(b)は周波数に対する位相 差を示す。周波数の増加に伴い，位相差は増加してお り $10 \mathrm{kHz}$ 以下では位相差 $0.4^{\circ}$ 以下となった。今回, 検証用に試作したロゴスキーコイルを用いた電流の位 置や角度, 周波数に対して変化する振幅誤差率, 位相 差は小さいことが分かった。また，試作したロゴスキ ーコイルは市販の電流センサと同程度な周波数特性を 有することが分かった。

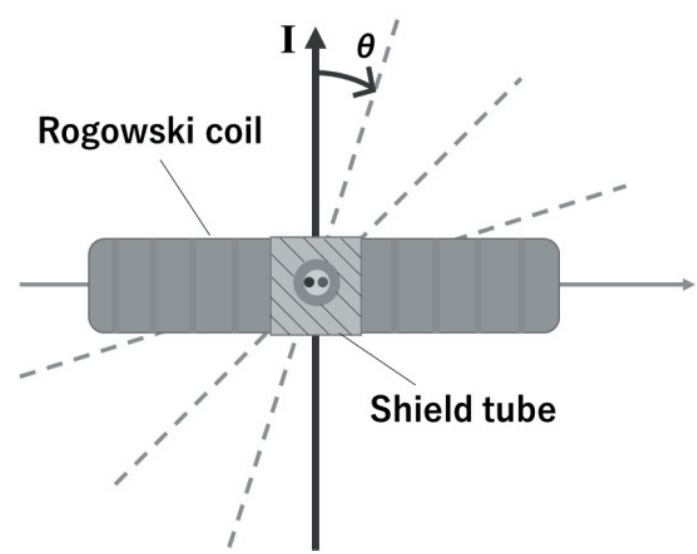

Fig. 5 Change in current angle.

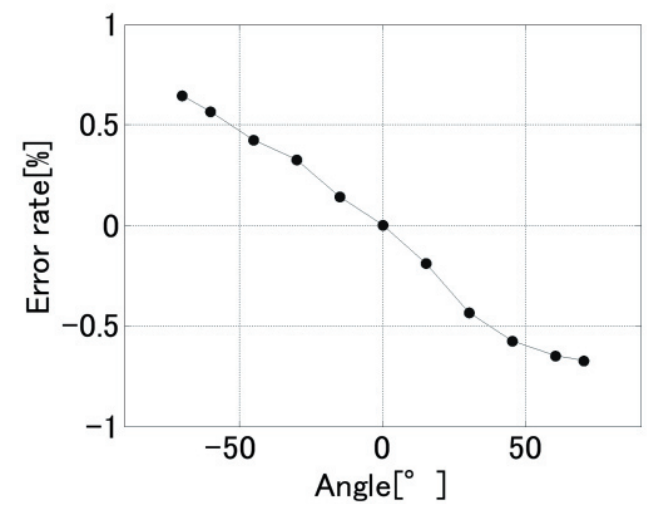

Fig. 6 Rate of change with current angle.

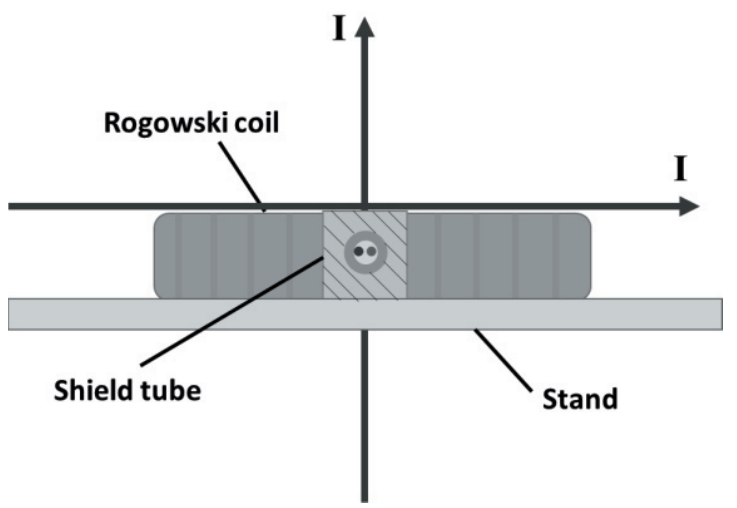

Fig. 7 Orthogonal current.

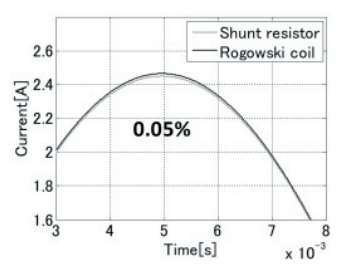

(a)Rogowski coil.

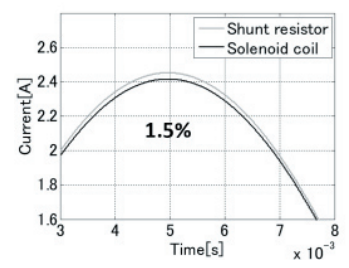

(b)Solenoid coil.
Fig. 8 Effects of orthogonal currents. 


\section{3 磁気特性測定}

\section{1 リングコア試料}

ロゴスキーコイル，環状ソレノイドコイル，市販の 電流センサ，シャント抵抗の 4 つの電流センサを用い て磁気特性測定を行った結果を報告する。使用した試 料は, $0.35 \mathrm{~mm}$ 厚の電磁鋼板を積層させたリング試料 である。リングコアの寸法は, 外径 $60 \mathrm{~mm}$, 内径 $50 \mathrm{~mm}$, 積厚 $5 \mathrm{~mm}$ である。これらのリングコアは, 電磁鋼板 を接着積層したものをワイヤ放電加工で切り出したも のである。励磁巻線は, 直径 $0.8 \mathrm{~mm}$ のホルマル線を 166 回巻いている。また, サーチコイルは直径 $0.32 \mathrm{~mm}$ のホルマル線を 1 回巻いている。

リングコア試料の鉄損 $W_{i}$ を以下の方法で算出した。サ 一チコイルの電圧 $v_{S}$ と式 (3) より励磁磁束密度を求 め, シャント抵抗を流れる励磁電流 $I_{e x}$ を各センサから の電圧加算出し, 有効磁路長 $L_{e}$ と式 (4) を用いて 励磁磁界強度 $H_{e x}$ を求める。この $B_{e x}$ と $H_{e x}$ 及び, 式 $(5)$ を用いて鉄損 $W_{i}$ を算出する。なお, $N_{S}$ はサーチコイル の巻き数, $S$ はサーチコイルの断面積, $N_{e}$ は励磁コイ ルの巻き数である。また， $\rho$ はコア材の密度，Tは励磁 電流の周期である。

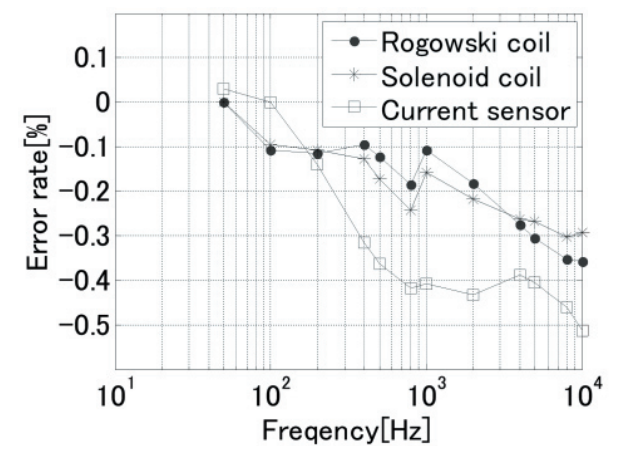

(a) Amplitude error rate based on shunt resistance.

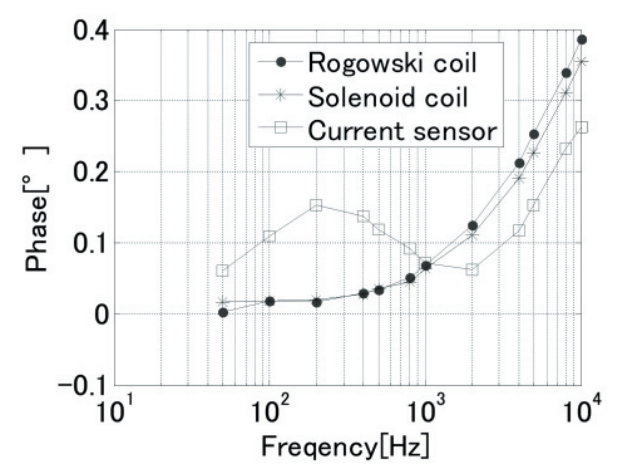

(b) Phase difference based on shunt resistance.

Fig. 9 Frequency characteristic.

$$
\begin{aligned}
& B_{e x}=-\frac{1}{N_{S} S} \int v_{S} d t \\
& H_{e x}=\frac{N_{e} I_{e x}}{L_{e}} \\
& W_{i}=\frac{1}{\rho T} \int_{T} H_{e x} \cdot \frac{d B_{e x}}{d t} d t
\end{aligned}
$$

\section{2 正弦波励磁下}

リングコア試料を正弦波励磁下で評価するための 磁気特性評価システムを Fig.10 に示す[5]。v ユータで取得し, 各センサからの電圧は 12 bit, $20 \mathrm{MS} / \mathrm{s}$ の A/D コンバータで取り込む。励磁磁束密度 $B_{\text {ex }}$ は, $\mathrm{D} / \mathrm{A}$ コンバータと高速パワーアンプを用いて生成し $B_{e x}$ の最大值 $\mathrm{B}_{\text {exmax }}$ を $0.8 \mathrm{~T}$ と設定し, 励磁周波数 $f_{e x}$ を $50 \sim 2 \mathrm{kHz}$ まで変化させた。なお，この際， $\mathrm{A} / \mathrm{D}$ コンバ 一タのサンプリング周波数は，1 MHzとし，5 kHz 成 分まで考慮した。さらに, 測定值として 16 周期分を同 期加算平均した值を用いた。

Fig.11 $2 \mathrm{kHz}$ 時の測定結果を示す。Fig.11(a)は正弦 波に制御された励磁磁束密度波形を示す。Fig.11(b)に 各センサから得られた励磁磁界強度波形を示す。各セ ンサの電流波形は同様の傾向であるが，拡大すると口 ゴスキーコイルの值が基準となるシャント抵抗と最も 近い值であった。Fig.11(c)は各センサから得られたヒ ステリシスループを示す。励磁磁界強度波形同様に拡 大寸るとロゴスキーコイルの值が基準となるシャント 抵抗と最も近い值である。各センサの周波数毎の鉄損 を Fig.12に， $2 \mathrm{kHz}$ 時の鉄損值とシャント抵抗を基準 とした場合の誤差率を Table 1 に示す。各センサであま り差はみられないが， $2 \mathrm{kHz}$ 時ではロゴスキーコイル の誤差率が約 0.8 \%と最も低く, 環状ソレノイドコイ ルが約 $4 \%$ と最も大きい結果となった。

\subsection{PWM 励磁下}

リングコア試料を PWM 励磁下で評価するための磁 気特性評価システムを Fig.13 に示す。先の正弦波励磁 下での評価システムの高速パワーアンプ部を PWM イ ンバータ(MWINV1R022)に置換したものである[6]。正 弦波励磁下同様 $v_{S}$ はコンピュータ A で取得し, 各セン サからの電圧は $12 \mathrm{bit}, 20 \mathrm{MS} / \mathrm{s}$ の A/D コンバータで取 り込む。更に, 変調波の周波数 $f_{m}$, キャリアの周波数 
$f_{c}$, 変調率 $m$ は，コンピュータ B を用いて設定する。 励磁磁束密度 $B_{e x}$ は, $\mathrm{D} / \mathrm{A}$ コンバータと高速パワーア ンプを用いて生成し $B_{e x}$ の最大值 $B_{\text {exmax }}$ を設定した。な お, この際, $\mathrm{A} / \mathrm{D}$ コンバータのサンプリング周波数は, $20 \mathrm{MHz}$ とし, $10 \mathrm{MHz}$ 成分まで考慮した。更に, 測定値 として 32 周期分を同期加算平均した值を用いた。 $f_{m}$ を $50 \mathrm{~Hz}, f_{c}$ を $2 \mathrm{kHz}, m$ を $0.4 ， B_{\text {exmax }}$ を $0.8 \mathrm{~T}$ に設 定した場合の測定結果を Fig.14 19, Table2 に示す。 Fig.14(a)は制御された磁束密度波形を示す。(b),(c),(d) はそれぞれシャント抵抗を比較としたロゴスキーコイ ル, 環状ソレノイドコイル, 市販の電流センサから得 られた磁界強度波形を示寸。市販の電流センサはノイ ズを多く含んでいるが，ロゴスキーコイルと環状ソレ ノイドコイルは基準となるシャント抵抗と同様な波形 となっている。Fig.15(a),(b),(c)はシャント抵抗を比較と したロゴスキーコイル, 環状ソレノイドコイル, 市販 の電流センサのヒステリシスループを示す。市販の電 流センサはノイズの影響により，そのループ形状が不 明確となっているが，ロゴスキーコイルと環状ソレ， イドコイルは基準となるシャント抵抗と同様の結果と なっている。Fig.16 は Fig.15(a),(b)のマイナーループを 拡大したものを示す。どちらもシャント抵抗と同様な 形状となっている。Table 2 に各センサから算出された 鉄損值とシャント抵抗を基準とした誤差率を示す。口 ゴスキーコイルがシャント抵抗と最も近い值を示し, $1.3 \%$ 程度であった。Fig.17 に各センサから得られた $H_{e x}$ の FFT 解析を行った高調波成分を示す。ロゴスキーコ イルの $50,150,250 \mathrm{~Hz}$ 成分はシャント抵抗と比較する

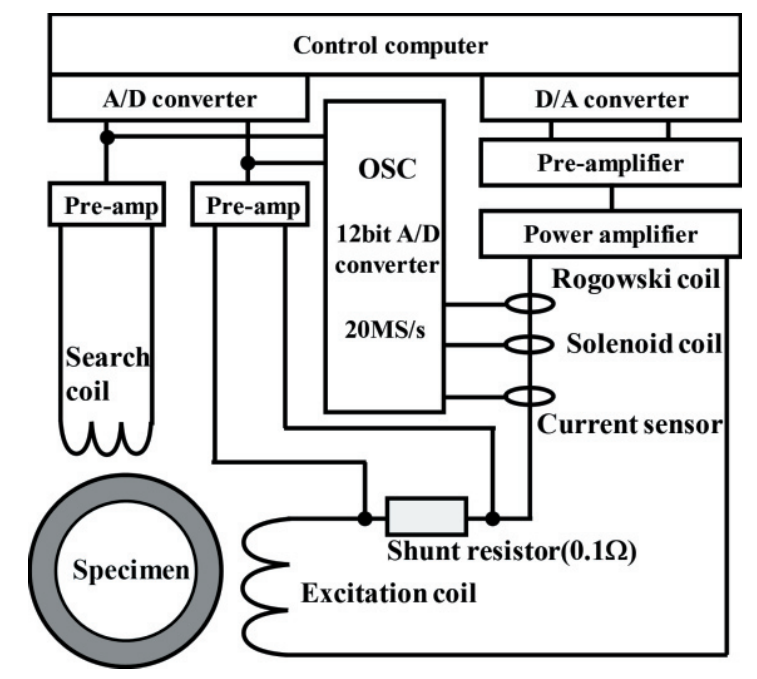

Fig. 10 Sinusoidal excitation measurement system.

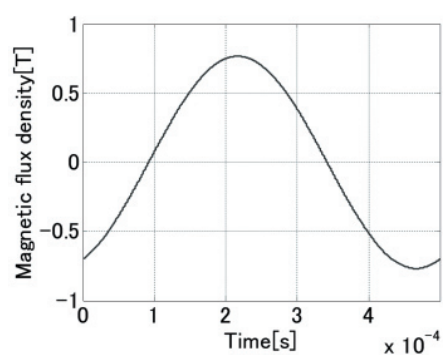

(a) Excitation magnetic flux density $B_{e x}$.

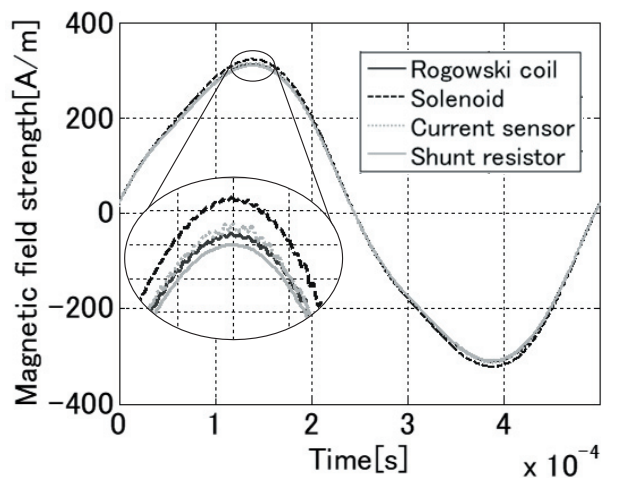

(b) Excitation magnetic field strength $H_{e x}$.

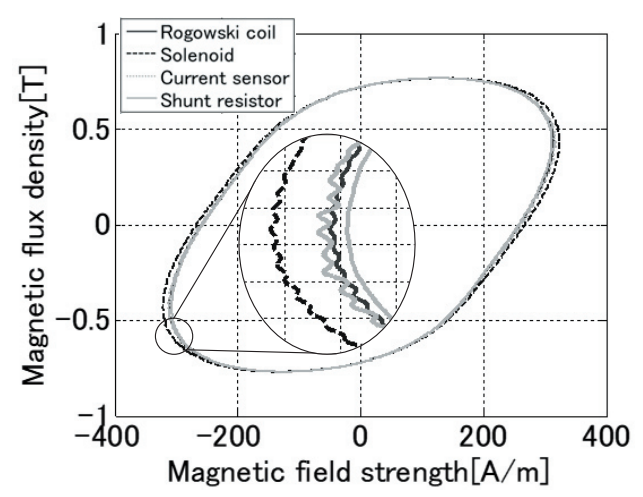

(c) $B$ - $H$ curve

Fig. 11 Measurement results under sinusoidal excitation. $\left(f_{m}=2 \mathrm{kHz}, \quad B_{\text {exmax }}=0.8 \mathrm{~T}\right)$

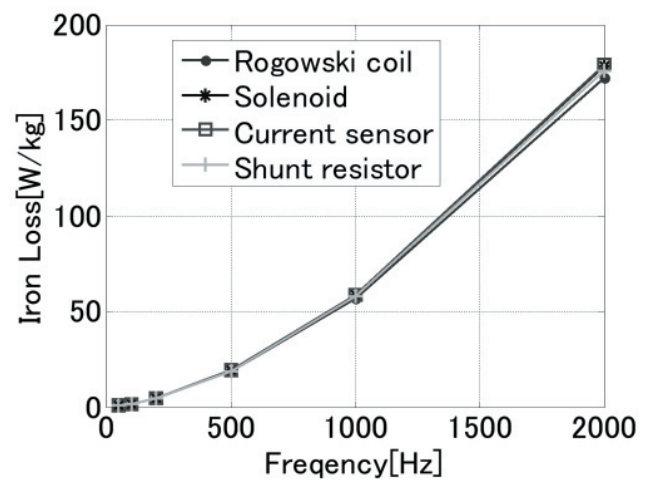

Fig. $12 W_{i}-f_{m} \cdot\left(f_{m}=50 \sim 2 \mathrm{kHz}, \quad B_{\text {exmax }}=0.8\right)$ 
Table 1 Iron loss under sinusoidal excitation. $\left(f_{m}=2 \mathrm{kHz}\right)$

\begin{tabular}{|c|c|c|}
\hline Sensor & Iron loss[W/kg] & Error rate[\%] \\
\hline Rogowski coil & 177.6 & 0.755 \\
\hline Solenoid coil & 183.6 & 4.153 \\
\hline Current sensor & 178.6 & 1.322 \\
\hline Shunt resistor & 176.3 & \\
\hline
\end{tabular}

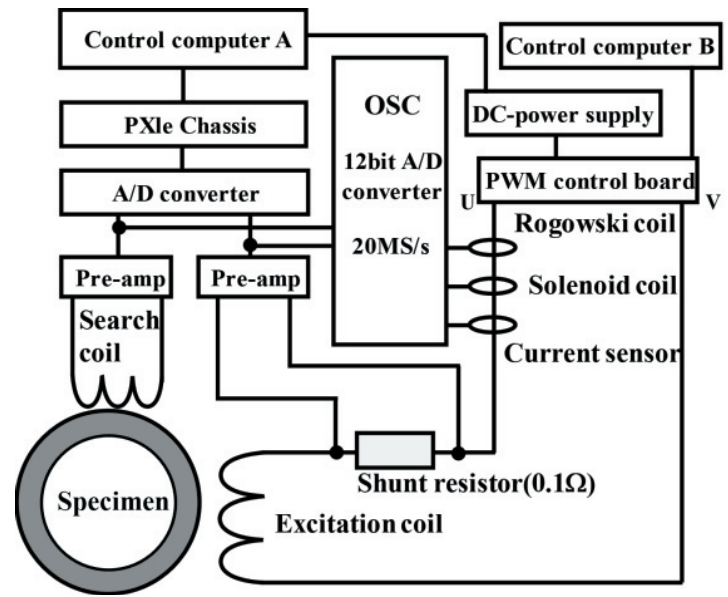

Fig. 13 PWM excitation measurement system.
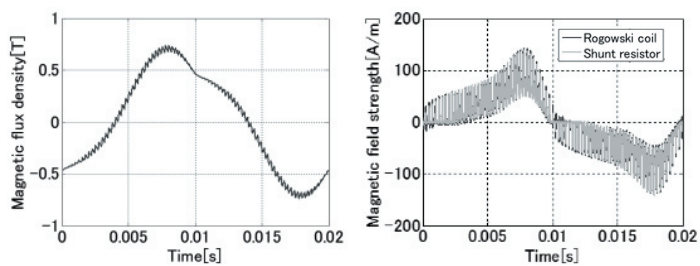

(a) $B_{e x}$.

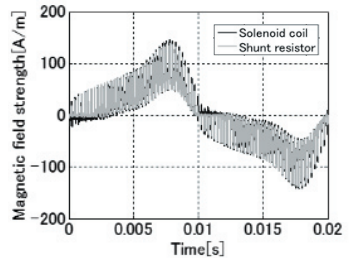

(b) $H_{e x}$ of Rogowski coil.

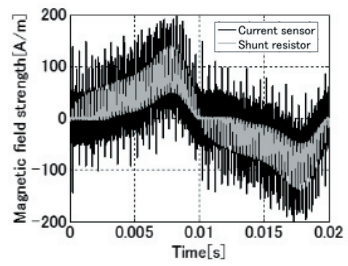

(c) $H_{e x}$ of Solenoid coil.

(d) $H_{e x}$ of Current sensor.

Fig. 14 Measurement results of $B_{e x}$ and $H_{e x}$.

$\left(f_{m}=50 \mathrm{~Hz}, f_{c}=2 \mathrm{kHz}, \quad m=0.4, \quad B_{\text {exmax }}=0.8 \mathrm{~T}\right)$

と誤差率 $6 \%$ 以下であったが, $350,450,550 \mathrm{~Hz}$ では $20 \%$ 程度，また， $4 \mathrm{k}, 8 \mathrm{k}, 12 \mathrm{kHz}$ 付近では $2 \%$ 程度となった。 Fig.18 は各センサの各周波数帯域で生じる磁界強度の 総和を示す。市販センサでは高調波成分を多く含むこ とが分かる。Fig.19 は Fig.18 を基にシャント抵抗を基 準として各センサの誤差率を示す。PWM 励磁のよう に高調波を多く含む場合, ロゴスキーコイルは $100 \mathrm{kHz}$ 以上の高調波の誤差率を抑えることができていること が分かる。

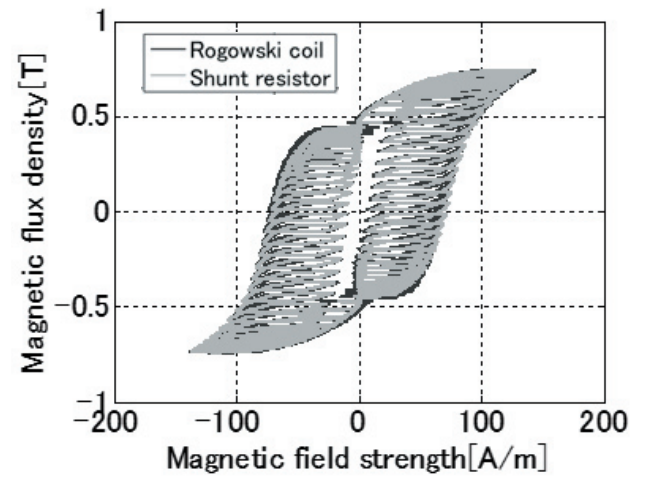

(a) $B-H$ curve of Rogowski coil.

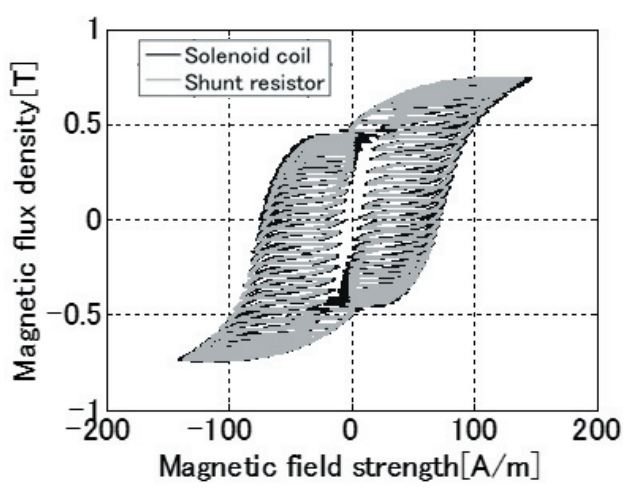

(b) $B-H$ curve of Solenoid coil.

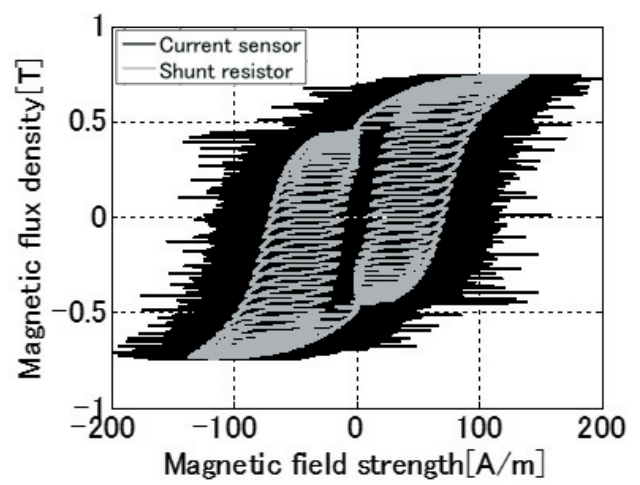

(c) $\mathrm{B}$ - $\mathrm{H}$ curve of Current sensor.

Fig. 15 Measurement results of $B$ - $H$ curve. $\left(f_{m}=50 \mathrm{~Hz}, f_{c}=2 \mathrm{kHz}, \quad m=0.4, \quad B_{\text {exmax }}=0.8 \mathrm{~T}\right)$
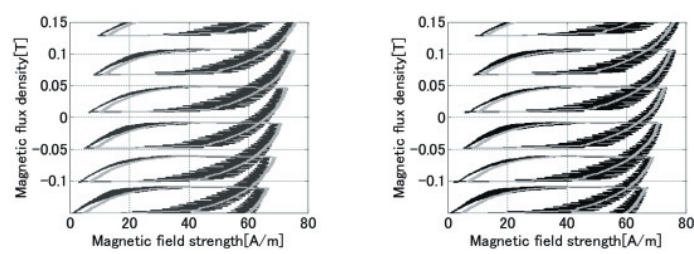

(a) Rogowski coil.

(b) Solenoid coil

Fig. 16 Enlarged view of Fig. 15. 
Table 2 Iron loss under PWM excitation.

\begin{tabular}{|c|c|c|}
\hline Sensor & Iron loss[W/kg] & Error rate[\%] \\
\hline Rogowski coil & 1.774 & 1.277 \\
\hline Solenoid coil & 1.785 & 1.889 \\
\hline Current sensor & 1.787 & 1.992 \\
\hline Shunt resistor & 1.752 & \\
\hline
\end{tabular}

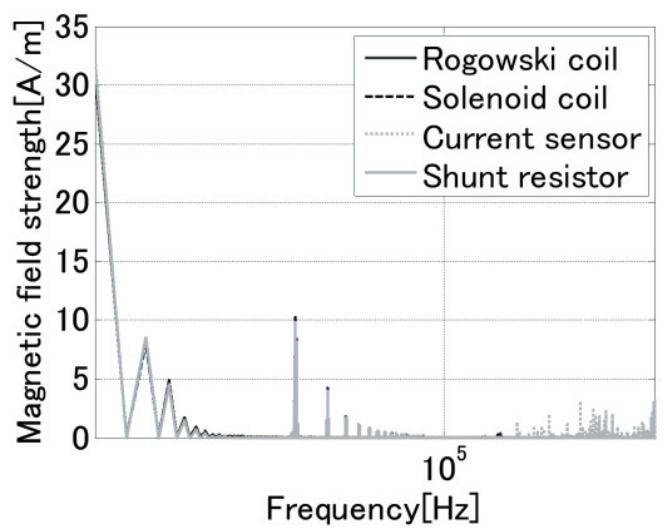

Fig. 17 Frequency component of each sensor.

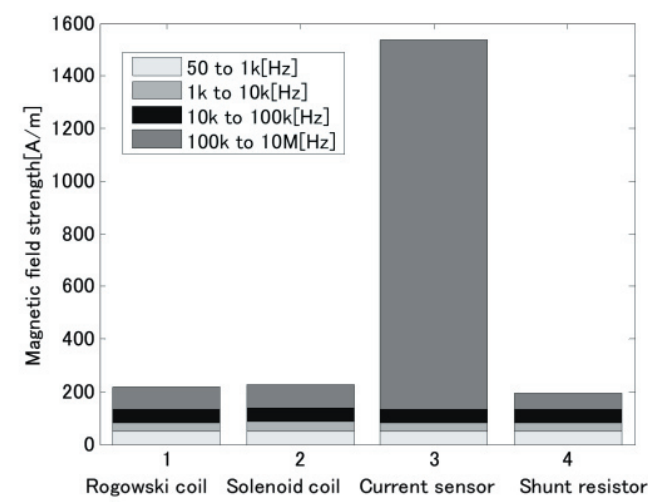

Fig. 18 Total magnetic field strength generated in the frequency band.

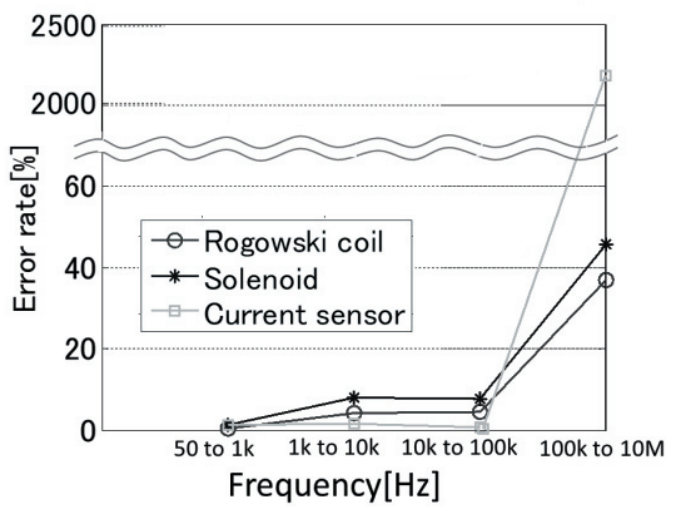

Fig. 19 Error rate in Fig.18 based on shunt resistance.
4 まとめ

本論文では，高調波・PWM 励磁下の電磁鋼板の正 確な磁気特性測定を目的として，ロゴスキーコイルを 試作し, シャント抵抗を基準として環状ソレノイドコ イルと市販の電流センサと比較を行った。高周波正弦 波励磁, PWM 励磁の両方において, 試作したロゴス キーコイルがシャント抵抗の磁界波形及び鉄損と最も 近い值を示した。よって, PWM 励磁下においてロゴ スキーコイルの有効性について確認することができた。 今後は，電流位置や角度に影響を受けないロゴスキー コイルの小型化や様々な PWM 励磁条件での測定によ り詳細な検証を行う予定である。

\section{謝辞}

本研究は，JSPS 科研費 17H01259(基盤研究(A))の助 成を受けて行われた。

\section{参考文献}

[1] 田中凌将，上野稜也，三枝香風，加治淳一，山下昂洋, 柳井武志, 中野正基, 福永博俊, 無電解めつき法により 作製した Fe-Ni 膜, 電気学会マグネティックス研究会資 料, MAG-19-096, pp. 21-24, 2019.

[2] 修理雄大, 若林大輔, 榎園正人, コアレス電流・磁界セ ンサ開発に向けたロゴスキーコイルの基礎的評価, 電気 学会マグネティックス研究会資料, MAG-19-038, pp. 2124, 2019.

[3] 林泉, 中野義映,「ロゴスキーコイルと磁気探針」, 電気 学会雑誌, Vol. 81, No. 874, pp. 1084-1092, 1961.

[4] 鈴木洋一郎, 河野秀一, 片岡良平, 木村友則, 桑野博喜 : 「積層基板構造による小型広帯域コイルの検討」, 日本 機械学会論文集，Vol.81，No.828 pp.1-8 (2015)

[5] 岡茂八郎, 榎園正人, 森祐司, 山崎一正, 極薄電磁鋼板 製ステータコアの鉄損評価のための各種励磁法の検討, 電気学会マグネティックス研究会資料, MAG-17-182, pp. 13-16, 2017.

[6] 岡茂八郎, 榎園正人, 清武博文, PWM インバータ励磁 下の電磁鋼板製リングコアの鉄損測定法の検討, 電気学 会マグネティックス研究会資料, MAG-19-038, pp. 1-4, 2019. 